\title{
Factors Influencing Passenger Satisfaction toward Waterway Transportation
}

\author{
Mahamudul Hasan ${ }^{1} \quad$ Kabita Karmaker ${ }^{2}$ \\ ${ }^{I}$ Assistant professor, Department of Marketing, Patuakhali Science and Technology University, Bangladesh \\ ${ }^{2}$ Faculty of Business Administration and Management, Patuakhali Science and Technology University, Bangladesh
}

Abstract - The study has been conducted to investigate the factors affecting customer satisfaction toward inland waterway transportation service in Bangladesh. The study has revealed that cost and management, staff attitude and behavior, safety and security, comfort and hygiene, availability of service and food \& decoration has significant effect on overall satisfaction. Moreover, Time management has no significant effect on customer satisfaction. The result also shows that overall satisfaction has positive relationship with repeat visit intention and positive word to mouth advertisements.

Keywords: Inland Waterway Transportation, Satisfaction, Repeat visit, Positive word of Mouth, Bangladesh.

\section{Introduction}

The inland shipping industry plays a very significant role in Bangladesh for carrying passengers and goods for many years. This industry provides naturally appropriate and comparatively cheaper means of transportation for carrying passengers and commodities particularly in the southern districts of the country. The water transport system is both widespread and well-connected with the rest of the transport arrangement in Bangladesh. In terms of traffic intensity, the inland waterway network generates about one-and-half million passenger-kilometers per routekilometer of waterway (Bangladesh Economic Review, 2004). The concentration of domestic ports and terminals is high with around three and half berthing facilities per one hundred route-kilometers. The density of passenger facilities on the inland waterways is also high at around 40 per 100 route-km.

Therefore, inland water transportation is an essential mode of transportation for building a balanced multimodal transport system in Bangladesh. Moreover, with the increase in population and the growing economy of the country, the waterways are getting congested as the inland waterways are not expanding significantly (Awal and Hoque, 2008). The Pakistan administration, in order to increase the role of water transport in the economic sector of the country, established five major inland ports with up to date facilities in Dhaka, Narayanganj, Chandpur, Barisal and Khulna. With the increase of commerce and industry in the post-Independence period, six more inland ports were upgraded and modernized since 1971 for easy movement of passengers and cargoes. These ports are Patuakhali, Nagarbari, Aricha, Dauladia Baghabari and Narshingdi.. Wayside terminals (Ghats) were provided since 1971 and at present there are more than one thousand terminals for the waterway passengers in Bangladesh. Many of those terminals are managed by BIWTA (Bangladesh Inland Water Transport Authority,) (Afrose and Ashraf, 2003).

Numerous studies have been conducted to measure passenger's satisfaction toward different modes of public transportations (Agarwal, 2008; Fellison and Friman,2008; Pullen,1993; Marquez et al,2014; Eboli and Mazzulla, 2007). . However, still now there is a serious lack of study on the factors influencing passenger's satisfaction in inland waterway transportation from the perspective of Bangladesh. Therefore, this study aims to analyze the factors that affect customer satisfaction toward waterway transportation in Bangladesh by answering the following research question: Which factors have significant influence on customer satisfaction toward waterway transportations in bangladesh? Does customer satisfaction influence repeat visit intention in waterway transportations? Is there any relation between repeat visit intentions toward inland waterway transportations and positive word of mouth . 


\section{Literature Review}

\subsection{Customer Satisfaction}

Customer satisfaction is a goal of each organization (Bagdonienè and Hopenienè, 2005) Customer satisfaction has been considered one of the most important factors in any industry or service due to its direct relation to customer retention. General customer satisfaction studies link the use or reuse of a commodity or service to the extent to which customers are satisfied. customer satisfaction is important to measure because of its significant impacts on firms' long-term performance and also customer purchasing behaviors. The academicians has associated high customer satisfaction with higher customer loyalty and positive reputation (Fornell, 1992; Anderson \& Sullivan, 1993; Wangnheim \& Bayon, 2004). Customer satisfaction is an important concept that deserves further interest. From consumer research, satisfaction is known to be of great value in understanding customers' perceptions and evaluations (Oliver 1997), repeatedly showing itself to be an important indicator of future customer behavior (Fornell 1992, Johnson \& Gustafsson 2000).

\subsection{Water Transportation in Bangladesh}

There is a $14000 \mathrm{~km}$ long river network in Bangladesh. In this network there are 700 rivers (BIWTA). The three major river systems of the Ganges, the Brahmaputra and the Meghna converge in Bangladesh to form one of the world's largest deltas (Jansen, et al., 1994). These three mighty rivers also create one of the most multifaceted river systems in the earth. The number of watercourses increases from northwest to southeast in Bangladesh. Before the advent of the road and rail transport the rivers were the main arteries of movement for passengers and cargoes. Cities, towns, villages and market centres all grew up along rivers and canals for easy transport. Indeed, the whole economy of Bangladesh depends on the waterways. The combined waters of the Ganges and the BrahmaputraJamuna meet the Meghna in a large confluence south of Chandpur, which can be as wide as $11 \mathrm{~km}$ during the monsoon. From this point southwards the Meghna becomes one of the largest rivers in Bangladesh. The rivers Padma and Jamuna are very unstable and are inclined to lateral migrations. Both rivers can be classified as braided channels that are indicative of high sediment loads and slow water flows (Rashid, 1991).

After the independence in 1971, a great number of people have moved from southern areas of Bangladesh to capital city and water transport has become very popular. Inter-district and intra-district movements within the southern districts of Barisal, Bhola, Patuakhali, Jhalokathi, Borguna, Pirozpur and their sub-districts are by water transport. These areas of Bangladesh are linked with capital city Dhaka by both water transport network and road transport network. However, most of the people prefer water transport due to its economic convenience. The main river-port of the Dhaka City is known as the Sadarghat port from where 200 small and large motor launches go to different destination daily (Hoque and Dewan, 2017).

\subsection{Customer Satisfaction toward Water Transport}

Customer satisfaction explains the performance of a firm and customer's reaction toward it. To summarize, satisfaction is increasingly being put forward as key to the future development of public transport, both in theory and in practice. In transport research, satisfaction has been discussed from policy context (cf. Hensher 2007). To evaluate the performance of of public transport, discussion from policy context is necessary. Factors shows clear signs of an industry generic structure consisting of four basic quality dimensions, i.e. safety/security, system (with supply and reliability items), comfort, and staff behavior (Markus Fellesson \& Margareta Friman 2008). The performance of public transport's has been evaluated from cost efficiency dimensions for a long period of time (e.g. Hensher 1995; Pullen, 1993). However, for the last few years service quality of public transportation has been evaluated in numerous research works (Alireza et al., 2011). Transportation service has been evaluated from frequency of the service, the punctuality, the comfort and cleanliness, the safety, the availability of information, the personnel courtesy, the fare and others. In addition to these factors, others aspects should be considered which are appreciated by each user and are highly reliant on the users' social and demographic characteristics; their context (i.e. geographical area, social class and type of service); the reason for travel; and the modes of transport used (e.g. Andreassen, 1995; Ganesan-Lim et al., 2008). 


\section{Methodology \& Conceptual framework}

\subsection{Population \& Sample}

The target population for this study is the passengers who have use the launch service from Dhaka to Barisal Route. This study is a descriptive research and quantitative in nature. The sample of the study consists of 100 passengers who travel frequently from Barisal to Dhaka through various launch services.

\subsection{Sampling Technique and Data Collection}

In this research, non-probability convenience sampling technique was used i.e., anyone who is available to be part of the survey can answer the question and data were collected from passengers through personal interviewing method. In this study a questionnaire form was used as a tool for collecting primary data. The secondary data has been collected from different sources such as previous research, different journals and articles related to the title.

\subsection{Questionnaire design}

In this study, self-administered Questionnaires have been used in the data collection, and the questionnaire is specially designed to meet the requirements of the research. The first part is about demographic information of respondent. The second part includes questions related to factors influencing passenger satisfaction, passenger satisfaction level, repeat visit intention and word of mouth intention. A category scale and Likert type scale questions been used where respondents had to make their level of agreement such as; Strongly Disagree, Disagree, neither agree nor Disagree (neutral), Agree and Strongly Agree. Scores of 1, 2, 3, 4, and 5 were assigned respectively for above mentioned categories.

\subsection{Data analysis}

The analysis of the study has been carried out through frequency distribution, Pearson correlation and regression analysis.

\subsection{Analytical model}

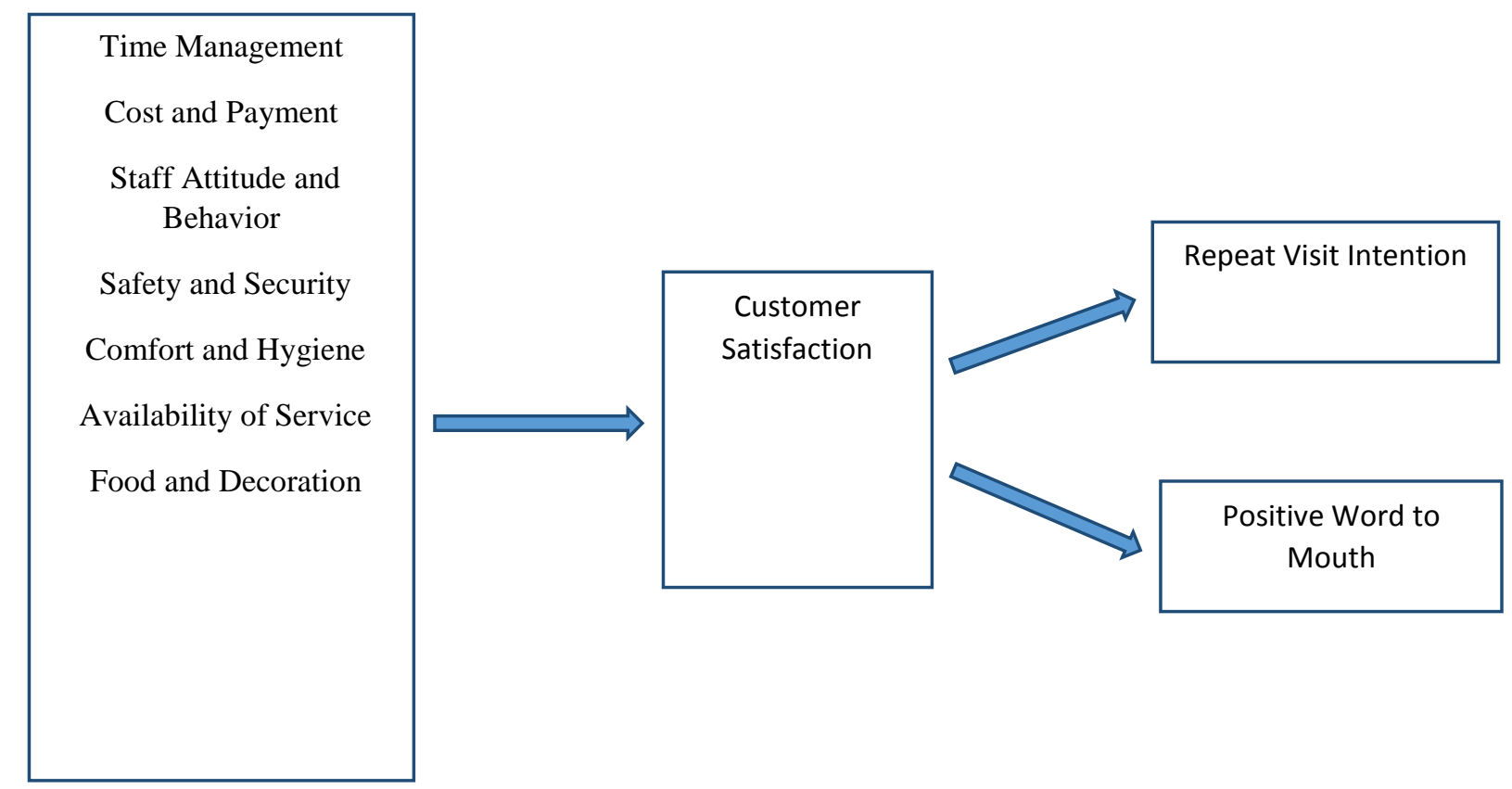

Based on the objectives of the study, literature review and conceptual framework the following hypotheses are proposed: 
H1: Time management, cost and payment, staff attitude and behavior, safety and security, comfort and hygiene, availability of service, food and decoration influence the customer satisfaction toward waterway transportation

$\mathrm{H} 2$ : Customer satisfaction influences repeat visit through waterway transportation

H3: Customer satisfaction influences positive word to mouth through waterway transportation.

H4: There is a strong association between time management, cost and payment, staff attitude and behavior, safety and security, comfort and hygiene, availability of service, food and decoration with customer satisfaction

H5: There is a strong association between repeat visit intention and positive word of mouth with customer satisfaction

\section{RESULT AND DISCUSSIONS}

The target population for this study is the customers who use the launch transportation service. We have taken about 100 samples on the people who have the experience of launch journey including all age group, gender. To assess the measurement, we use percentage, mean and regression (model summery, ANOVA, coefficient).

\subsection{Demographic profile of respondents}

\section{Table 1}

Demographic profile of the Respondents

\begin{tabular}{|c|c|c|}
\hline Variables & Frequency & Percent \\
\hline \multicolumn{3}{|c|}{ Respondent's Age Group } \\
\hline Bellow 20 & 10 & $10 \%$ \\
\hline 20 to 25 & 69 & $69 \%$ \\
\hline 25 to 30 & 11 & $11 \%$ \\
\hline Above 30 & 10 & $10 \%$ \\
\hline Total & 100 & $100 \%$ \\
\hline \multicolumn{3}{|l|}{ Gender } \\
\hline Male & 60 & $60 \%$ \\
\hline Female & 40 & $40 \%$ \\
\hline Total & 100 & $100 \%$ \\
\hline \multicolumn{3}{|c|}{ Marital status } \\
\hline Married & 25 & $25 \%$ \\
\hline Unmarried & 75 & $75 \%$ \\
\hline Total & 100 & $100 \%$ \\
\hline \multicolumn{3}{|c|}{ Education level of the respondents } \\
\hline Below SSC & 7 & $7 \%$ \\
\hline $\mathrm{SSC}$ & 3 & $3 \%$ \\
\hline HSC & 14 & $14 \%$ \\
\hline
\end{tabular}




\begin{tabular}{|l|l|l|}
\hline Honors & 65 & $65 \%$ \\
\hline Masters & 11 & $11 \%$ \\
\hline Total & 100 & $100 \%$ \\
\hline Frequency of using this \\
transportation & & \\
\hline once in a week & 5 & $5 \%$ \\
\hline Once in a quarter & 7 & $7 \%$ \\
\hline Once in a month & 39 & $39 \%$ \\
\hline Once in a year & 49 & $49 \%$ \\
\hline Total & 100 & $100 \%$ \\
\hline Service class preference & frequency & Percentage \\
\hline Dake & 31 & $31 \%$ \\
\hline Cabin & 47 & $47 \%$ \\
\hline Sofa & 13 & $13 \%$ \\
\hline VIP cabin & 9 & $9 \%$ \\
\hline total & 100 & $100 \%$ \\
\hline
\end{tabular}

The analysis of demographics reveals that majority of consumers are male (69\%), maximum people are age between 20-25 (60\%), most of them are unmarried (75\%) and educational qualification of majority are honors level $(65 \%)$. Most of the people use the transportation once a year (49\%). Most preferable service class is cabin $(47 \%)$.

Table 2

Summary of Regression Analysis

\begin{tabular}{|c|c|c|c|c|c|c|c|}
\hline Hypothesis & $\begin{array}{l}\text { Independent } \\
\text { variable }\end{array}$ & $\begin{array}{l}\text { Dependent } \\
\text { variable }\end{array}$ & $\begin{array}{l}\mathbf{R} \\
\text { Square }\end{array}$ & $\begin{array}{l}\text { Adjusted } \\
\text { R Square } \\
\end{array}$ & F value & Significance & $\begin{array}{l}\text { Hypothesis } \\
\text { tested }\end{array}$ \\
\hline \multirow[t]{7}{*}{ H1 } & $\begin{array}{l}\text { Time } \\
\text { management }\end{array}$ & $\begin{array}{l}\text { Customer } \\
\text { satisfaction }\end{array}$ & 0.22 & 0.012 & 2.197 & 0.141 & Rejected \\
\hline & $\begin{array}{l}\text { Cost and } \\
\text { payment }\end{array}$ & $\begin{array}{l}\text { Customer } \\
\text { satisfaction }\end{array}$ & 0.109 & 0.100 & 12.007 & 0.001 & Accepted \\
\hline & $\begin{array}{l}\text { Staff attitude } \\
\text { and behavior }\end{array}$ & $\begin{array}{l}\text { Customer } \\
\text { satisfaction }\end{array}$ & 0.138 & 0.130 & 15.730 & 0.000 & Accepted \\
\hline & $\begin{array}{l}\text { Safety and } \\
\text { security }\end{array}$ & $\begin{array}{l}\text { Customer } \\
\text { satisfaction }\end{array}$ & 0.127 & 0.118 & 14.238 & 0.000 & Accepted \\
\hline & $\begin{array}{l}\text { Comfort and } \\
\text { hygiene }\end{array}$ & $\begin{array}{l}\text { Customer } \\
\text { satisfaction }\end{array}$ & 0.173 & 0.165 & 20.501 & 0.000 & Accepted \\
\hline & $\begin{array}{l}\text { Availability of } \\
\text { service }\end{array}$ & $\begin{array}{l}\text { Customer } \\
\text { satisfaction }\end{array}$ & 0.137 & 0.128 & 15.587 & 0.000 & Accepted \\
\hline & $\begin{array}{l}\text { Food and } \\
\text { decoration }\end{array}$ & $\begin{array}{l}\text { Customer } \\
\text { satisfaction }\end{array}$ & 0.062 & 0.052 & 6.442 & 0.013 & Accepted \\
\hline $\mathrm{H} 2$ & $\begin{array}{l}\text { Customer } \\
\text { satisfaction }\end{array}$ & Repeat visit & 0.385 & 0.378 & 61.273 & 0.000 & Accepted \\
\hline H3 & $\begin{array}{l}\text { Customer } \\
\text { satisfaction }\end{array}$ & $\begin{array}{l}\text { Positive word } \\
\text { to mouth }\end{array}$ & 0.360 & 0.353 & 55.038 & 0.000 & Accepted \\
\hline
\end{tabular}


For testing hypothesis 1, customer satisfaction is taken as the dependent variable and time management, cost and payment, staff attitude and behavior, safety and security, comfort and hygiene, availability of service, food and decoration are taken as the independent variables. At 5\% level of significance, our p-value of time management is 0.141 which is greater than the significant value 0.05 . Therefore, time management shows no significant effects on overall customer satisfaction. P-value of cost \& payment is 0.001 which is less significant table value 0.05 . So, cost \& payment has significant effects on customer satisfaction. P-value of staff attitude \& behavior is 0.000 which is less than significant table value 0.05 . So, staff attitude \& behavior has significant effects on customer satisfaction Pvalue of safety \& security is 0.000 which is less significant table value 0.05 . So, safety \& security has significant effects on customer satisfaction. P-value of comfort and hygiene is 0.000 which is less than significant table value 0.05. So, comfort and hygiene has significant effects on customer satisfaction-value of availability of service is 0.000 which is less than significant table value 0.05 . So, availability of service has significant effects on customer satisfaction-value of food and decoration is 0.013 which is less significant table value 0.05 . So, food and decoration has significant effects on customer satisfaction. Among seven dimension, six dimensions' show significant effects on customer satisfaction. So, hypothesis 1 is partially accepted.

For testing hypothesis 2, repeat visit intention has been taken as the dependent variable and customer satisfaction as the independent variable. At $5 \%$ level of significance, our p-value is 0.000 which is less than the significant value 0.05 . So our hypothesis is accepted that indicates customer satisfaction has significant effect on repeat visit intention.

For testing hypothesis 3, positive word to mouth has been taken as the dependent variable and customer satisfaction as the independent variable. At $5 \%$ level of significance, our p-value is 0.000 which is less than the significant value 0.05. So our hypothesis is accepted that indicates customer satisfaction has significant effects on positive word to mouth.

Table 3

\section{Summary of Correlation Analysis}

\begin{tabular}{|c|c|c|c|c|c|c|c|c|c|c|c|}
\hline & & $\begin{array}{l}\text { Customer } \\
\text { satisfacti } \\
\text { on }\end{array}$ & $\begin{array}{l}\text { Time } \\
\text { Manageme } \\
\text { nt }\end{array}$ & $\begin{array}{l}\text { Cost } \\
\& \text { Payme } \\
\text { nt }\end{array}$ & $\begin{array}{l}\text { Staff } \\
\text { attitude } \\
\& \\
\text { Behavi } \\
\text { or } \\
\end{array}$ & $\begin{array}{l}\text { Safety } \\
\& \\
\text { Securit } \\
\text { y }\end{array}$ & $\begin{array}{l}\text { Comfo } \\
\text { rt \& } \\
\text { Hygie } \\
\text { ne }\end{array}$ & $\begin{array}{l}\text { Availabili } \\
\text { ty of } \\
\text { service }\end{array}$ & $\begin{array}{l}\text { Food \& } \\
\text { Decoration }\end{array}$ & Repeat visit & $\begin{array}{l}\text { Positive word } \\
\text { of mouth }\end{array}$ \\
\hline $\begin{array}{l}\text { Customer } \\
\text { satisfaction }\end{array}$ & $\begin{array}{l}\text { Pearson } \\
\text { Correlati } \\
\text { on } \\
\text { Sig. (2- } \\
\text { tailed) } \\
\mathrm{N}\end{array}$ & 100 & $\begin{array}{l}.148 \\
.141 \\
100\end{array}$ & $\begin{array}{l}.330 * * \\
.001 \\
100\end{array}$ & $\begin{array}{l}.372 * * \\
.001 \\
100\end{array}$ & $\begin{array}{l}.356 * * \\
.000 \\
100\end{array}$ & $\begin{array}{l}.416^{* *} \\
.000 \\
100\end{array}$ & $\begin{array}{l}.370 * * \\
.000 \\
100\end{array}$ & $\begin{array}{l}.248^{*} \\
.013 \\
100\end{array}$ & $\begin{array}{l}.620^{* * *} \\
.000 \\
100\end{array}$ & $\begin{array}{l}.600 * * \\
.000 \\
100\end{array}$ \\
\hline Repeat visit & $\begin{array}{l}\text { Pearson } \\
\text { Correlati } \\
\text { on } \\
\text { Sig. (2- } \\
\text { tailed) } \\
\mathrm{N}\end{array}$ & $\begin{array}{l}.620 * * \\
.000 \\
100\end{array}$ & $\begin{array}{l}.092 \\
.363 \\
100\end{array}$ & $\begin{array}{l}.252 * \\
.011 \\
100\end{array}$ & $\begin{array}{l}.291 * * \\
.003 \\
100\end{array}$ & $\begin{array}{l}.403 * * \\
.000 \\
100\end{array}$ & $\begin{array}{l}.288^{*} \\
.004 \\
100\end{array}$ & $\begin{array}{l}.206^{*} \\
.040 \\
100\end{array}$ & $\begin{array}{l}.153 \\
.129 \\
100\end{array}$ & 100 & $\begin{array}{l}.563 * * \\
.000 \\
100\end{array}$ \\
\hline $\begin{array}{l}\text { Positive word } \\
\text { of mouth }\end{array}$ & $\begin{array}{l}\text { Pearson } \\
\text { Correlati } \\
\text { on } \\
\text { Sig. (2- } \\
\text { tailed) } \\
\text { N }\end{array}$ & $\begin{array}{l}.600 * * \\
.000 \\
100\end{array}$ & $\begin{array}{l}.250 \\
.012 \\
100\end{array}$ & $\begin{array}{l}.210^{*} \\
.036 \\
100\end{array}$ & $\begin{array}{l}.317 * * \\
.001 \\
100\end{array}$ & $\begin{array}{l}.248^{*} \\
.013 \\
100\end{array}$ & $\begin{array}{l}.357 * * \\
.000 \\
100\end{array}$ & $\begin{array}{l}.318^{* *} \\
.001 \\
100\end{array}$ & $\begin{array}{l}.189 \\
.060 \\
100\end{array}$ & $\begin{array}{l}.563^{* * *} \\
.000 \\
100\end{array}$ & 100 \\
\hline
\end{tabular}


Table 3 shows that the relationship between Time management, cost and payment, staff attitude and behavior, safety and security, comfort and hygiene, availability of service, food and decoration and customer satisfaction are statistically significant. Therefore, a hypothesis 4 is accepted.

The relationship between customer satisfaction and revisit intention is positive and statistically significant. The relationship between customer satisfaction and positive word of mouth is positive and statistically significant. Therefore, hypothesis 5 is also accepted.

\section{CONCLUSION\& MANAGERIAL IMPLICATIONS}

The service quality of Waterway transportation is the combination of many factors which in turns paves way for satisfaction of the customers who use this transportation service. If the performance of the factors is not adequately met, or poorly implemented, the customers would visit once, but will not refer it to others and themselves will not use this service again. All the service dimensions have significant effect on overall customer satisfaction. Cost and payment, staff attitude and behavior, safety and security, comfort and hygiene, availability of service, food and decoration positively affect on customer satisfaction. 42 percent people agreed that they are satisfied with the service. About $53 \%$ of the population will use the service again and $52 \%$ of population will recommend the transportation. Overall satisfaction has a positive relationship with repeat visit intention and positive word of mouth.

On the foundation of finding and result, we can see that cost and management, staff attitude and behavior, safety and security, comfort and hygiene, availability of service and food \& decoration have significant effect on overall satisfaction. So, the transportation authority should focus on all six of the aspects. The waterway transportation authority should simplify the payment system. Staff attitude \& behavior has been assigned the greatest relative importance by the respondents. This implies that the behavior of staff - their friendliness, politeness, cooperation, promptness, efficiency, knowledge level, trustworthiness, appearance, etcetera-can reinforce or decrease the satisfaction level of the customers. So legal obligations and skill requirements, service firms should seek to recruit staff to fill specific roles, train them to effectively handle the customers, and enable systems to monitor their speech, behavior and performance. Since safety and security during the journey are considered highly important by the customers, those should be afforded more attention by the waterway transportation authority. authority must focus on cleanliness of the vehicle and keep entering/exiting clean. Contracts can be entered into with other parties to provide better facilities of food and drinks. The waterway authorities should also ensure that proper service in terms of up-to date information and clean bed sheets and blankets are being provided to customers.

\section{Limitations of the study and Directions for future research}

There are some limitations for conducting this research which are given below:

- Only a single mode of waterway transportation has been selected for the study.

- The sample size was very small.

- Respondents were not included from all over country.

Inland waterway transportation is an essential mode of transportation for building a balanced multimodal transport system to confront the upcoming development challenges. The author proposes the following further research:

- Further research could be extended to other parts of the country so that the findings may be more useful

- There is a need to explore more independent variables that can have an impact on passenger satisfaction.

\section{References}

[1] Afrose Huq, N., \& Ashraf Mahmmood, D. (2003). Launch disasters in Bangladesh: a geographical study. Geografia, 1(2), 14-25.

[2] Anderson, E. W., \& Sullivan, M.W. (1993), 'The Antecedents and Consequences of Customer Satisfaction for Firms', Marketing Science, Vol. 12, No. 2, (spring), pp. 125-143.

[3] Andreassen TW. (1995) atisfaction with public services: The case of public transportation. Journal of Services Marketing 9: 30-41. 
[4] Alireza, M. Antimicrobial activity and chemical composition of essential oils of chamomile from Neyshabur, Iran. Journal of Medicinal Plants Research Vol. 6(5), pp. 820-824.

[5] Awal, Z. I., \& Hoque, M. M. (2008, May). Some Aspects of Water Transport Accident and Injury Problems in Bangladesh. In Proceedings of the 10th Pacific Regional Science Conference Organisation (PRSCO) Summer Institute (pp. 15-17).

[6] Bagdonienė L., Hopenienė R. (2005). Paslaugų marketingas ir vadyba: Vadovėlis. Kaunas: Technologija.

[7] Fellesson,M., Friman,M.(2008), Perceived Satisfaction with Public Transport Service in Nine European Cities, Journal of the Transportation Research Forum, Vol. 47, No. 3

[8] Fornell, C. (1992), 'A National Customer Satisfaction Barometer: The Swedish Experience’, Journal of Marketing, Vol. 56, (January), pp. 6-21

[9] Ganesan-Lim, C., Russell-Bennett, R. \& Dagger, T. (2008) The impact of service contact type and demographic characteristics on service quality perceptions. Journal of Services Marketing, 22, 550-561

[10] Hensher, David A. “Bus Transport: Economics, Policy and Planning.” Research in Transportation Economics 18, (2007): 1-507.

[11] Huq, N. A., \& Dewan, A. M. (2017). Launch disasters in Bangladesh: A geographical study. Geografia-Malaysian Journal of Society and Space, 2(1).

[12] Johnson,Michael,D. and Anders Gustafesson. Improving Customer Satisfaction, Loalty and Profit:An Integrated Measurement and Management System .San Fransisco, Jossey-Bass, 2000.

[13] Jensen, C., Soo, M., and Snodgrass, R. (1994c). Unifying Temporal Data Models via a Conceptual Model. Information Systems, 19(7):513547

[14] Oliver, Richard L. Satisfaction. A Behavioral Perspective on the Consumer. New York, McGrawHill, 1997.

[15] Pullen, W.T. 1993. 'Definition and Measurement of Quality of Service for Local Public Transport Management"', Transport Reviews, 13(3): 247-64.

[16] Reeti Agarwal.(2008)."Public Transportation and Customer Satisfaction: The Case of Indian Railways"GLOBAL BUSINESS REVIEW, 9:2 (2008): 257-272 Los Angeles/London/New Delhi/Singapore

[17] Rashid, Harun Er; 1991, geography of Bangladesh; University press limited, Second revised edition, P. 33.

[18] Saunders, M. N. K. (2012). Choosing research participants. In G. Symon, \& C. Cassell (Eds.), The practice of qualitative organizational research: Core methods and current challenges (pp. 37- 55).

[19] Sekaran, U. (1992). Research Methods for Business - A skill building approach. (2nd Ed). United States of America: John Wiley \& Sons, Inc

[20] Wangenheim, Tomás Bayón, (2004) "The effect of word of mouth on services switching: Measurement and moderating variables", European Journal of Marketing, Vol. 38 Issue: 9/10, pp.1173-1185. 